\title{
Morphological and behavioural correlates of reproductive success in Atlantic cod Gadus morhua
}

\author{
Sherrylynn Rowe ${ }^{1, *}$, Jeffrey A. Hutchings ${ }^{2}$, Jon Egil Skjæraasen ${ }^{3}$, Louise Bezanson ${ }^{2}$ \\ ${ }^{1}$ Fisheries and Oceans Canada, Bedford Institute of Oceanography, PO Box 1006, Dartmouth, Nova Scotia B2Y 4A2, Canada \\ ${ }^{2}$ Department of Biology, Dalhousie University, Halifax, Nova Scotia B3H 4J1, Canada \\ ${ }^{3}$ Department of Biology, University of Bergen, 5020 Bergen, Norway
}

\begin{abstract}
We tested the hypothesis that reproductive success is randomly distributed within spawning aggregations of Atlantic cod Gadus morhua, a broadcast-spawning marine fish for which no parental care is provided. Based on microsatellite DNA-parentage assignment of 8913 offspring from 4 large ( $\mathrm{n}=52$ to 93 ) experimental spawning aggregations, we quantified individual variation in male reproductive success and evaluated the degree to which this variation could be explained by aspects of morphology, condition, and spawning behaviour. Reproductive success was highly skewed, with more than $80 \%$ of the offspring within each group sired by 2 to 7 individuals. Body size and agonistic interactions initiated were positively associated with male reproductive success within each group. The lengths of fins prominent during courtship and mating were also correlated with reproductive success within one of the spawning groups for which data were available. Our observations are consistent with the hypotheses that some form of intrasexual competition or mate choice is a constituent of the mating system of this species and that the ratio of effective to census population size in broadcast-spawning marine fishes is very small.
\end{abstract}

KEY WORDS: Mating system $\cdot$ Fertilization success $\cdot$ Mating success $\cdot$ Reproductive skew $\cdot$ Broadcast spawning

Resale or republication not permitted without written consent of the publisher

\section{INTRODUCTION}

Mating systems have received insufficient attention for the indirect but significant influence they can have on population dynamics and conservation biology (Møller \& Legendre 2001, Quader 2005). This is particularly true of marine fishes, many of which are at historic population lows and for which very little is known of their behaviour during the spawning period (Rowe \& Hutchings 2003). Fish live in an environment that makes it challenging to observe reproductive behaviour and patterns of parentage. Nonetheless, many fishes are known to exhibit external fertilization, which provides an opportunity for intense sperm competition and promotes a variety of male reproductive strategies. Often, this takes the form of individual males investing either in the attraction and monopolization of females or in sperm production and the parasitizing of pair spawnings (Taborsky 1998). In some studies (e.g. DeWoody et al. 2000, Jones \& Hutchings 2002), molecular tools have been applied to examine the reproductive success of male fish employing alternative tactics, although most of these studies have focused on freshwater-spawning species that deposit gametes in nests. By comparison, few studies have addressed the relative contribution of competing males in broadcast-spawning marine fishes (Avise et al. 2002).

The Atlantic cod Gadus morhua is a bet-hedging species, releasing multiple batches of eggs throughout multiple breeding seasons. The eggs are released directly into the oceanic environment (broadcasted) and no parental care is provided for them. Attaining maturity across a broad range of sizes ( 35 to $85 \mathrm{~cm}$ ) and ages ( 2 to $7 \mathrm{yr}$ ) throughout the species range (Brander 1994, COSEWIC 2003), females release their annual egg complement (numbering hundreds of thousands, often millions, of 1.25 to $1.75 \mathrm{~mm}$ eggs) in batches over 
3 to 6 wk (Chambers \& Waiwood 1996, Kjesbu et al. 1996) within a 6 to 12 wk spawning season (Myers et al. 1993).

Despite a wealth of fisheries research on this species, the mating system of Atlantic cod, like that of most broadcast-spawning fishes, is not well understood (Avise et al. 2002, Rowe \& Hutchings 2003). Captive breeding studies (Brawn 1961a, Hutchings et al. 1999) have shown that the release of eggs is immediately preceded by a 'ventral mount' in which the male, whilst grasping the female with his larger pelvic fins (Skjæraasen et al. 2006) and matching her swimming speed, positions himself beneath her. Upon commencement of spawning, the mating pair may be joined by 'satellite males' that swim amongst the eggs, releasing sperm and fertilizing eggs in competition with the primary male (Hutchings et al. 1999, Rakitin et al. 2001, Bekkevold et al. 2002). Before mounting attempts, agonistic interactions are often seen among males and may allow behaviourally dominant individuals to establish 'territories' (Brawn 1961a, Hutchings et al. 1999). Successful ventral mounts also appear to be preceded by courtship behaviour, which has been described as an intense 'flaunting' display during which the courting male moves alongside and in front of the female with median fins fully erect while 'swimming with an excited, jerky, undulating movement with many unnecessary circles' (Brawn 1961a). Reproduction is also associated with sound produced using 3 pairs of drumming muscles exterior to the swimbladder wall (Brawn 1961b, Rowe \& Hutchings 2004); these sounds, which appear to be only produced by males (Brawn 1961b), have been hypothesized to reinforce threat displays directed towards other males (Brawn 1961b, Rowe \& Hutchings 2006) and to be a sexually selected characteristic upon which females base an active choice of spawning partner (Engen \& Folstad 1999, Hutchings et al. 1999, Rowe \& Hutchings 2006).

The apparent complexity in mating behaviour revealed by previous studies suggests that reproductive success is not random amongst male Atlantic cod. To test this hypothesis, we examined how morphological and behavioural variables thought to affect reproductive success influence the number of offspring sired by each male. Based on behavioural, morphological, and genetic data obtained from 4 large ( $\mathrm{n}>50$ ) groups of cod spawning in a very large $\left(684 \mathrm{~m}^{3}\right)$ experimental tank, we quantified associations between reproductive success (i.e. number of offspring sired) and several potential correlates thereof (body size, condition, drumming muscle mass, fin size, aggression, and ventral mounting activity). Our data also allowed us to examine individual variability in male reproductive success, a primary determinant of effective population size.

\section{MATERIALS AND METHODS}

Examination of parental fish and sampling of offspring. We examined cod from 3 spatially distinct areas in the Northwest Atlantic: Western Scotian Shelf, Southern Gulf of St. Lawrence, and Eastern Scotian Shelf, identified by the Northwest Atlantic Fishery Organization (NAFO) as divisions $4 \mathrm{X}, 4 \mathrm{~T}$, and $4 \mathrm{~W}$, respectively. Fish from each NAFO division were captured approximately 2 to $3 \mathrm{wk}$ prior to their annual spawning periods, individually tagged (using unique combinations of one or two $7.5 \mathrm{~cm}$ long, coloured T-bar anchor tags which were inserted into the dorsal musculature; Hutchings et al. 1999), and taken to the $15 \mathrm{~m}$ diameter, $4 \mathrm{~m}$ deep Pool Tank at Dalhousie University, where they were allowed to spawn undisturbed. Reproductive success was quantified in 4 groups of individuals. Groups 1 and 3 were 2 separate groups of cod from Western Scotian Shelf that spawned in 2001 (25 females and 27 males, ranging from 42 to $78 \mathrm{~cm}$ in length) and 2002 (25 females and 29 males, ranging from 54 to $105 \mathrm{~cm}$ in length), respectively. The spawning period for Western Scotian Shelf cod encompassed December through March. Group 2 comprised Southern Gulf of St. Lawrence cod that spawned from May through July 2001 (41 females and 18 males, ranging from 50 to $70 \mathrm{~cm}$ in length). Group 4 comprised cod from Eastern Scotian Shelf that spawned in November and December 2002 (56 females and 37 males, ranging from 34 to $84 \mathrm{~cm}$ in length). Cod were maintained at densities similar to those reported for spawning individuals in the wild (Morgan et al. 1997), experienced water temperatures of approximately $8^{\circ} \mathrm{C}$ and ambient photoperiods, and were fed Shurgain ${ }^{\circledR} 8 \mathrm{~mm}$ fish feed daily. Fresh seawater was pumped continuously into the tank.

The behaviour of individuals in Groups 1 and 2 was observed throughout the spawning periods from a platform above the tank. During these direct observations, each individual was monitored continuously for 3 min within the last $8 \mathrm{~h}$ of daylight each day (Group 1: between 08:00 and 16:00 h on $54 \mathrm{~d}$; Group 2: between 12:00 and 20:00 h on $34 \mathrm{~d}$ ), and the incidence of 5 agonistic behaviours was documented: (1) chase (swimming toward a swimming fish), (2) approach (swimming toward a stationary fish), (3) bite (physical contact between one fish's mouth and another fish's body or fin), (4) nip (an attempted bite, i.e. an opening and closing of the mouth near another fish's body or fin), and (5) prod (contact between one fish's snout and another fish's body) (Hutchings et al. 1999). Individuals were examined in varying order each day.

Courtship behaviour was infrequent relative to agonistic behaviour and seldom observed during $3 \mathrm{~min}$ focal fish watches. Consequently, to examine courtship 
activity for one of the spawning groups (Group 2), behaviour was recorded daily during the last $8 \mathrm{~h}$ of daylight from 15 May through 14 July 2001, using 4 ceiling-mounted video cameras and a colour videotape recorder. Subsequent to the spawning season, all videotapes were reviewed (totaling $488 \mathrm{~h}$ of video coverage) to document the incidence of courtship behaviour, particularly ventral mounts, as well as the identities of the fish involved (whenever possible). This camera array was not available for data collection for Groups 1, 3 or 4 .

Out-flowing surface water was sieved through a plankton net which was checked daily at approximately 16:00 h for the presence of the positively buoyant spawned eggs. Microscopic examination of random samples of eggs collected in this manner indicated that almost all had been fertilized within the previous $24 \mathrm{~h}$. Each egg batch was then incubated at approximately $8^{\circ} \mathrm{C}$ in $20 \mathrm{l}$ containers with circulating seawater and aeration. When eggs were within approximately $24 \mathrm{~h}$ of hatching (Groups 1, 2, and 3) or larvae were within 7 d post-hatching (Group 4), a random sample of several thousand offspring from each batch was collected and stored in ethanol for subsequent genetic analysis.

Experiments were terminated and fish sacrificed when no eggs had been collected for at least $5 \mathrm{~d}$. Blood samples were obtained from each individual and preserved in ethanol for pedigree analysis. We recorded total length of each individual to the nearest $\mathrm{mm}$, as well as total mass and gonad mass to the nearest $0.5 \mathrm{~g}$. Somatic mass was calculated as total mass less the gonad mass. We determined sex by observation of gross morphology of the gonad. For individuals in Groups 1, 2, and 4, estimates of pelvic fin size were obtained by measuring the length of the longest ray in the pelvic fin. In addition, for Groups 1 and 2, we measured the lengths of the longest fin rays of all median fins. All aspects of fin size were measured to the nearest mm, using a caliper. The 3 pairs of drumming muscles were extracted by forceps from the surrounding tissue (Rowe \& Hutchings 2004) and their combined dry mass was measured to the nearest $0.0001 \mathrm{~g}$ for each fish in Groups 1, 2, and 4. Unfortunately, due to fin damage, we were unable to determine the lengths of all median fins of 3 individuals from Group 1 and these individuals were excluded from our analyses of correlates of reproductive success.

Genetic analysis. DNA was extracted from blood of parental fish, using a Qiagen genomic extraction kit, and from whole offspring, following the extraction method described by Jones \& Hutchings (2002). The number of daily samples for which incubated offspring were available for analysis ranged between 20 (Group 4) and 38 (Group 1). Given time and financial constraints, and to maximize the number of samples across the spawning periods, our objective was to genotype 75 to 100 of the several thousand offspring that were usually available from each daily batch of collected eggs. On a few occasions, low egg/larval survival led to fewer than 75 offspring being available for genotyping. The number of genotyped offspring from each daily batch averaged $80.3 \pm 20.3 \mathrm{SD}$ (range: 11 to 171), resulting in totals of 2931, 1633, 2652, and 1697 offspring genotyped for the full spawning period from Groups 1, 2, 3 and 4, respectively.

From a variety of available cod microsatellite DNA loci, 3 tetranucleotide repeat loci, Gmo8, Gmo19, and Gmo37, and 1 trinucleotide repeat locus, Gmo35, were chosen to be run on all samples (with the exception of those from Group 3), based on their high levels of heterozygosity and genotyping reliability (Miller et al. 2000). In cases where these loci proved insufficient in determining parentage, 2 tetranucleotide repeat loci, Gmo34 (Miller et al. 2000) and Mae9 (a haddock Melanogrammus aeglefinus microsatellite DNA locus; O'Reilly et al. 2002), were also examined. For cod from Group 3, the following loci were run on each sample: Gmo8, Gmo19, Gmo34, Gmo35, and Tch5 (a walleye pollock Theragra chalcogramma microsatellite DNA locus; O'Reilly et al. 2000). Loci were amplified using polymerase chain reaction conditions specified by Miller et al. (2000) and O'Reilly et al. (2000, 2002), samples were run on $6 \%$ denaturing acrylamide gels, and microsatellite alleles or bands were visualized using an FMBIO II (Hitachi). For parental fish, all loci were amplified and run 3 times to ensure correct genotyping. Standard individuals were run on all gels to check consistency in fragment lengths. Allelic data for offspring and their putative parents were analysed with PAPA 2.0 (Duchesne et al. 2002) to determine parentage assignments for fish from each of the 4 groups. More than $95 \%$ of the offspring were assigned parentage to both a mother and father in each group. Offspring for which full parentage could not be unambiguously established were excluded from our analyses.

Data analyses. Differences among males in the number of offspring sired during the spawning season were assessed in relation to aspects of morphology, condition, and behaviour using a generalized linear model of count data with Poisson error (Crawley 2002). Using S-Plus (Version 6.1), we fitted a maximal model (for each group) and then simplified it by sequentially removing non-significant $(\alpha=0.05)$ explanatory variables to obtain a minimal adequate model. To adjust for overdispersion of the data (dispersion parameter for minimal adequate models ranged from 43 to 187), model simplification was conducted using an F-test instead of a $\chi^{2}$-test (Crawley 2002). 
In our maximal models, we included total length as a metric of body size. The residuals of the regression of somatic mass on total body length for each group were included in the maximal models as a metric of condition. This metric of condition is based on the premise that a heavier body mass for a given length corresponds to increased general well-being of individuals. Somatic mass was selected for use in this analysis because it excluded the mass of the gonad, which can vary significantly and independently of fish condition between seasons and within populations. In addition, because available energy reserves will be located in somatic tissues as opposed to germ cells, somatic mass may be considered a good reflection of condition. To examine the association between reproductive success and drumming muscle mass, we controlled for the influence of body size on drumming muscle mass (Rowe \& Hutchings 2004) using the residuals of the regression of drumming muscle mass on somatic mass in the maximal models.

To assess the association between reproductive success and median fin size, we first undertook a principal component analysis (PCA) to construct a variable that represented an amalgamation of the sizes of the median fins thought to be of importance during courtship displays (Brawn 1961a). Following Engen \& Folstad (1999), we included the lengths of the longest fin rays of the 2 most anterior dorsal fins and of the 2 ventral fins in our analysis. The PCAs were undertaken separately for males in Groups 1 and 2 (the only groups for which median fin data were available). Interestingly, the loadings on the first principal component (PC1) differed somewhat between the 2 groups. Among males in Group 1, the lengths of all 4 fins had relatively high positive loadings (range: 0.45 to 0.55 ), suggesting that the PC1, which explained $87 \%$ of the variability in the original variables, distinguished individuals characterized by comparatively tall median fins from those with comparatively small median fins. By contrast, among males in Group 2, the loadings of the anterior and posterior ventral fins on PC1 (83\% of the explained variation) were very high ( 0.88 and 0.44 , respectively), suggesting a separation of males that possessed relatively tall ventral fins from those with relatively short ventral fins (the loadings of the 2 dorsal fin lengths were less than 0.20). We controlled for the influence of body size on fin size using the residuals of the regression of fin length (pelvic fin length or PC1 of the PCA describing median fin lengths) on total body length in the maximal models.

In cases where residuals were derived using ANOVA, mass and length data were log-transformed to meet the assumptions of normality and to linearize allometric relationships otherwise described by a power function; an exception was the regression of
PC1 (describing median fin lengths) on total body length, as some of the PC1 scores were negative values.

The aggressiveness of each male was determined by the number of observed agonistic interactions initiated by that male during the sum of all daily 3 min focal fish watches for which he was monitored; this variable was included in the maximal models for Groups 1 and 2 . The total number of ventral mounts initiated by individual males on females (a metric of mating success) in the video recordings was also included as an explanatory variable in the maximal model for Group 2.

\section{RESULTS}

Body size did not differ between sexes within spawning groups (Rowe et al. 2007). The average lengths $( \pm 1 \mathrm{SE})$ of cod in each group were as follows-Group 1 males: $53.7 \pm 1.6 \mathrm{~cm}$, females: $56.7 \pm 2.0 \mathrm{~cm}$; Group 2 males: $58.0 \pm 0.8 \mathrm{~cm}$, females: $57.9 \pm 0.7 \mathrm{~cm}$; Group 3 males: $72.7 \pm 1.4 \mathrm{~cm}$, females: $74.9 \pm 2.2 \mathrm{~cm}$; Group 4 males: $44.9 \pm 1.2 \mathrm{~cm}$, females: $49.9 \pm 1.2 \mathrm{~cm}$. Based on the genetic analyses, the minimum percentage of females known to spawn within each group ranged between $40 \%$ (Group 1) and 100\% (Group 3).

Male reproductive success was highly variable within spawning groups. The percentage of offspring sired by the most successful male ranged between 18\% (Group 3) and 68\% (Group 4; Fig. 1). In all groups, more than $80 \%$ of offspring were sired by the 2 to 7 most successful males, while some males had no

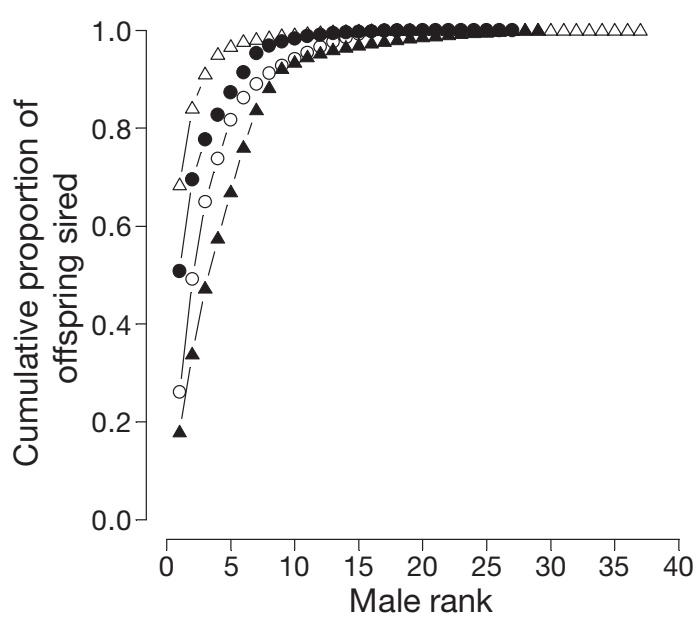

Fig. 1. Gadus morhua. Cumulative proportion of offspring sired by male Atlantic cod ranked from most to least successful. •: Western Scotian Shelf cod in 2001 (Group 1); O: Southern Gulf of St. Lawrence cod in 2001 (Group 2); $\mathbf{\Delta}$ : Western Scotian Shelf cod in 2002 (Group 3); $\Delta$ : Eastern Scotian Shelf cod in 2002 (Group 4) 
fertilization success (percentage of males for which fertilization success was 0 ranged between $3 \%$ [ $n=1$ ] for Group 3 and $54 \%$ [n = 20] for Group 4). The coefficient of variation (CV) in number of offspring sired was considerably greater in Group 4 (4.24) and Group 1 (2.76) relative to the other 2 groups examined (Group 3: 1.54; Group 2: 1.44) and this corresponded with relatively high coefficients of variation in body size (Group 1: 0.16; Group 4: 0.16; Group 3: 0.10; Group 2: 0.06).

Preliminary examination of the data suggested that there might be positive associations between the number of offspring sired and male body length, condition, drumming muscle mass, median fin length, agonistic interactions initiated, and ventral mounts initiated (Table 1). In particular, the most reproductively successful males (those that sired $\geq 80 \%$ of the offspring within a group) tended to have larger values for each of the above-mentioned traits than the remaining males in each spawning group. However, these associations may not necessarily be strong insofar as the most reproductively successful male did not always demonstrate the largest value for all traits. Pelvic fin length was greater among the most reproductively successful males in Group 1, but there was no apparent positive association between pelvic fin length and reproductive success in the other 2 groups for which these data were available (Table 1).

For all groups examined, the minimal adequate model describing the number of offspring sired included male body length as an explanatory variable
(Table 2). In Groups 1 and 2, for which the number of agonistic interactions initiated was quantified, this behavioural variable also remained in the minimal adequate model. The number of offspring sired tended to increase with body size (Fig. 2) and with number of agonistic interactions initiated by individuals during the spawning season (Fig. 3). Among cod in Group 1, the lengths of the pelvic and median fins were also of import (Table 2). Other morphological (post-spawning body condition and drumming muscle mass) and behavioural (number of ventral mounts initiated) traits appeared to show no significant association with male reproductive success.

The variability in reproductive success explained by the minimal adequate model was considerably greater in groups for which behavioural data were available (Table 2). Within Group 1, the minimal adequate model contained body length, pelvic fin length, median fin length, and agonistic interactions initiated as explanatory variables; removal of each of these individual variables from the model resulted in a decrease in the explained variation by $8.7,18.4,8.3$, and $19.4 \%$, respectively. Amongst Group 2 cod, body length and agonistic behaviour accounted for the greatest amount of variation in reproductive success. The variation explained by the minimal adequate model was reduced by $16.5 \%$ with the removal of body length and by $99.5 \%$ with the removal of agonistic interactions initiated. Body length was the only significant determinant of male reproductive success in Groups 3 and 4.

Table 1. Gadus morhua. Morphological and behavioural attributes (mean \pm SE) of (Rank a) the most reproductively successful male, (Rank b) the most reproductively successful males (i.e. those that sired $\geq 80 \%$ of the offspring within a group), and (Rank c) the remaining males within each of 4 captive groups of spawning Atlantic cod (Group 1: Western Scotian Shelf cod, 2001; Group 2: Southern Gulf of St. Lawrence cod, 2001; Group 3: Western Scotian Shelf cod, 2002; Group 4: Eastern Scotian Shelf cod, 2002)

\begin{tabular}{|c|c|c|c|c|c|c|c|c|c|}
\hline Group & Rank & $\mathrm{n}$ & $\begin{array}{l}\text { Body } \\
\text { length } \\
\text { (cm) }\end{array}$ & Condition $^{a}$ & $\begin{array}{l}\text { Drumming } \\
\text { muscle mass }\end{array}$ & $\begin{array}{c}\text { Pelvic } \\
\text { fin length }\end{array}$ & $\begin{array}{l}\text { Median } \\
\text { fin length }^{\mathrm{d}}\end{array}$ & $\begin{array}{c}\text { Agonistic } \\
\text { interactions } \\
\text { initiated }\end{array}$ & $\begin{array}{c}\text { Ventral } \\
\text { mounts } \\
\text { initiated }\end{array}$ \\
\hline 1 & $\begin{array}{l}\mathrm{a} \\
\mathrm{b} \\
\mathrm{c}\end{array}$ & $\begin{array}{r}1 \\
4 \\
20\end{array}$ & $\begin{array}{c}72.8 \\
67.2 \pm 4.1 \\
51.4 \pm 1.5\end{array}$ & $\begin{array}{c}-0.024 \\
0.009 \pm 0.037 \\
-0.002 \pm 0.026\end{array}$ & $\begin{array}{c}-0.012 \\
0.006 \pm 0.067 \\
-0.001 \pm 0.035\end{array}$ & $\begin{array}{c}0.015 \\
0.012 \pm 0.008 \\
-0.002 \pm 0.007\end{array}$ & $\begin{array}{c}-4.059 \\
0.755 \pm 2.183 \\
-0.151 \pm 1.058\end{array}$ & $\begin{array}{c}8.0 \\
7.3 \pm 2.7 \\
1.0 \pm 0.4\end{array}$ & \\
\hline 2 & $\begin{array}{l}\mathrm{a} \\
\mathrm{b} \\
\mathrm{c}\end{array}$ & $\begin{array}{r}1 \\
5 \\
13\end{array}$ & $\begin{array}{c}56.5 \\
60.2 \pm 2.0 \\
57.1 \pm 0.6\end{array}$ & $\begin{array}{c}0.145 \\
0.056 \pm 0.035 \\
-0.022 \pm 0.034\end{array}$ & $\begin{array}{c}0.343 \\
0.099 \pm 0.076 \\
-0.038 \pm 0.061\end{array}$ & $\begin{array}{c}0.010 \\
-0.004 \pm 0.014 \\
0.001 \pm 0.006\end{array}$ & $\begin{array}{c}61.360 \\
14.243 \pm 11.870 \\
-5.478 \pm 1.158\end{array}$ & $\begin{array}{c}43.0 \\
23.6 \pm 10.1 \\
1.9 \pm 0.5\end{array}$ & $\begin{array}{c}25.0 \\
6.0 \pm 4.8 \\
1.7 \pm 1.3\end{array}$ \\
\hline 3 & $\begin{array}{l}\mathrm{a} \\
\mathrm{b} \\
\mathrm{c}\end{array}$ & $\begin{array}{r}1 \\
7 \\
22\end{array}$ & $\begin{array}{c}74.0 \\
79.2 \pm 3.4 \\
70.6 \pm 1.2\end{array}$ & $\begin{array}{c}0.021 \\
0.004 \pm 0.012 \\
-0.001 \pm 0.014\end{array}$ & & & & & \\
\hline 4 & $\begin{array}{l}\mathrm{a} \\
\mathrm{b} \\
\mathrm{c}\end{array}$ & $\begin{array}{r}1 \\
2 \\
35\end{array}$ & $\begin{array}{c}57.0 \\
52.5 \pm 4.5 \\
44.5 \pm 1.2\end{array}$ & $\begin{array}{c}0.028 \\
0.017 \pm 0.010 \\
-0.001 \pm 0.010\end{array}$ & $\begin{array}{c}0.108 \\
0.039 \pm 0.069 \\
-0.002 \pm 0.038\end{array}$ & $\begin{array}{c}-0.033 \\
-0.001 \pm 0.032 \\
0.000 \pm 0.004\end{array}$ & & & \\
\hline \multicolumn{10}{|c|}{$\begin{array}{l}\text { a Residual somatic mass after controlling for body length } \\
{ }^{b} \text { Residual drumming muscle mass after controlling for somatic mass } \\
{ }^{c} \text { Residual pelvic fin length after controlling for body length } \\
{ }^{d} \text { Residual PC1 score (from a principal component analysis describing median fin lengths) after controlling for body length }\end{array}$} \\
\hline
\end{tabular}


Table 2. Gadus morhua. Minimal adequate model describing the number of offspring sired in relation to morphological and behavioural traits of males within each of 4 spawning groups of Atlantic cod (Group 1: Western Scotian Shelf cod, 2001; Group 2: Southern Gulf of St. Lawrence cod, 2001; Group 3: Western Scotian Shelf cod, 2002; Group 4: Eastern Scotian Shelf cod, 2002)

\begin{tabular}{|c|c|c|c|c|c|}
\hline Group & Explanatory variables & $\begin{array}{c}\text { Null } \\
\text { deviance }\end{array}$ & $\begin{array}{l}\text { Residual } \\
\text { deviance }\end{array}$ & $\begin{array}{l}\text { Residual } \\
\text { df }\end{array}$ & $\begin{array}{c}\text { Explained } \\
\text { variation }(\%)\end{array}$ \\
\hline 1 & $\begin{array}{l}\text { Body length }+ \text { pelvic fin length }{ }^{\mathrm{a}}+\text { median fin length } \\
+ \text { agonistic interactions }\end{array}$ & 9290.2 & 1454.8 & 19 & 84.3 \\
\hline 2 & Body length + agonistic interactions & 2525.9 & 645.2 & 15 & 74.5 \\
\hline 3 & Body length & 5043.5 & 3406.9 & 27 & 32.5 \\
\hline 4 & Body length & 8472.9 & 6548.3 & 35 & 22.7 \\
\hline
\end{tabular}

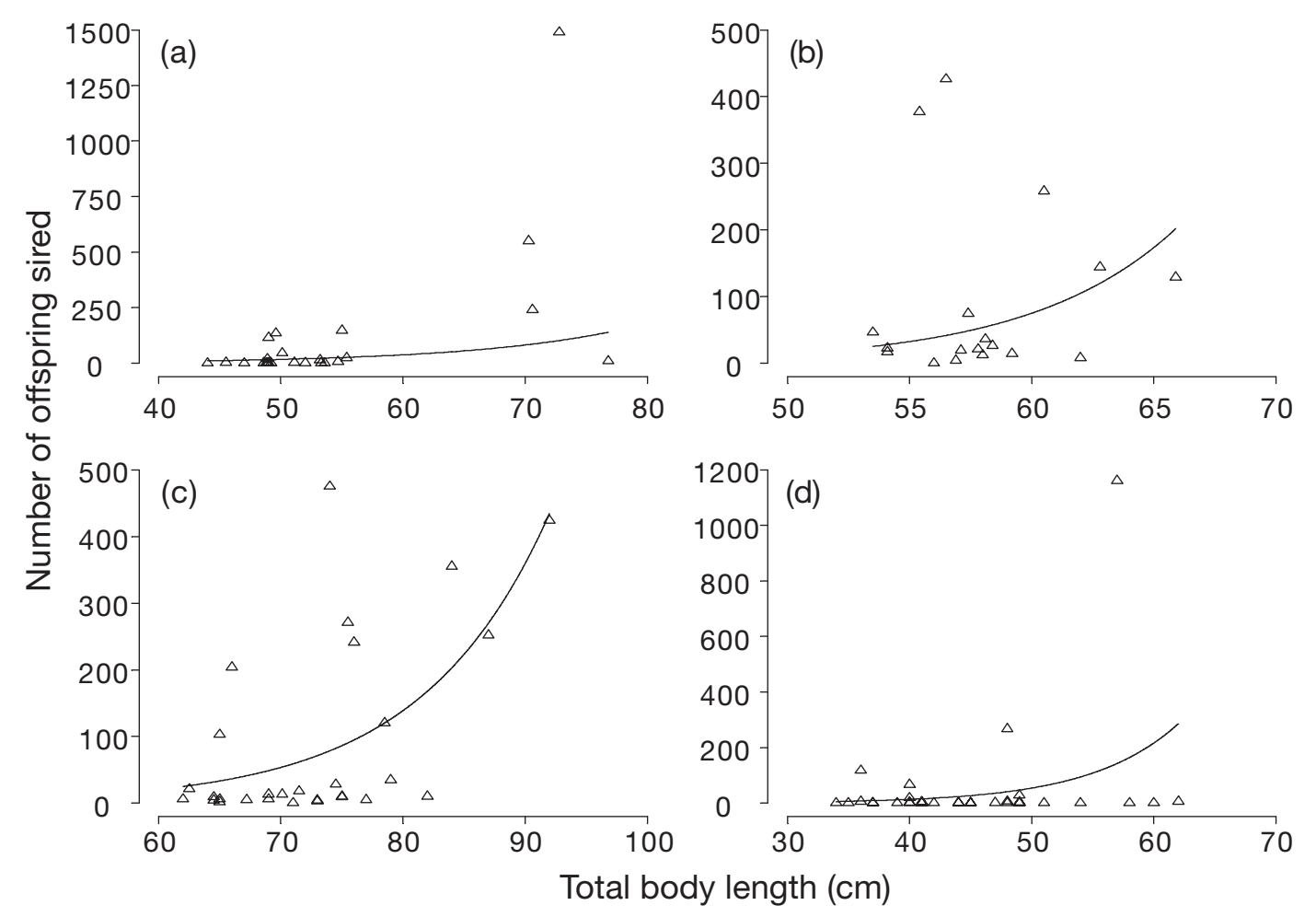

Fig. 2. Gadus morhua. Number of offspring sired in relation to total body length for male Atlantic cod from (a) Western Scotian Shelf in 2001 (Group 1), (b) Southern Gulf of St. Lawrence in 2001 (Group 2), (c) Western Scotian Shelf in 2002 (Group 3), and (d) Eastern Scotian Shelf in 2002 (Group 4). Lines indicate values predicted by the minimal adequate model for each group with any additional explanatory variables held constant at the mean observed values

\section{DISCUSSION}

Reproduction by male Atlantic cod is influenced by morphology and behaviour. In all groups for which data were available, reproductive success consistently increased with male body length and with the number of agonistic interactions initiated. Comparison of these 2 correlates of reproductive success showed that the number of agonistic encounters initiated by a given male was a better predictor of the number of offspring sired than body size. In addition to the body size and behaviour correlates, the lengths of pelvic and median fins were positively associated with reproductive success in one of the groups for which such data were available.

Previous investigators have hypothesized that agonistic interactions and large body size may enable some males to exclude others from areas in which they preferentially engage in courtship and spawning 


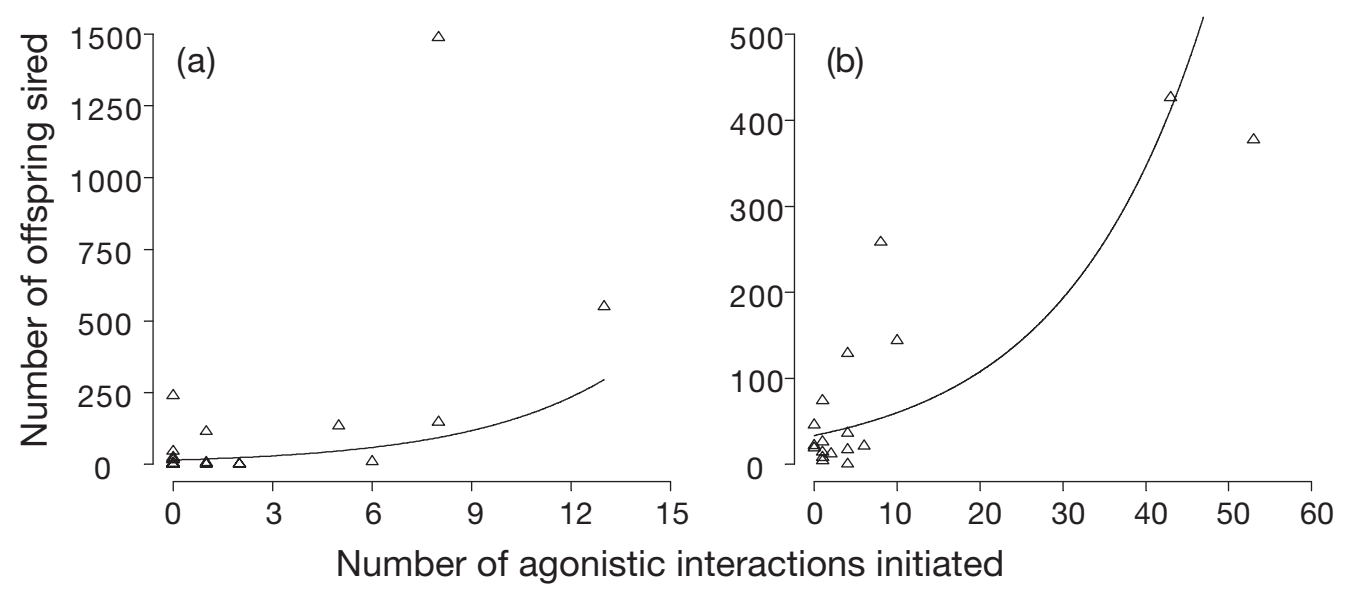

Fig. 3. Gadus morhua. Number of offspring sired in relation to number of agonistic interactions initiated towards other individuals by male Atlantic cod from (a) Western Scotian Shelf in 2001 (Group 1), and (b) Southern Gulf of St. Lawrence in 2001 (Group 2). Lines indicate values predicted by the minimal adequate model for each group with any additional explanatory variables held constant at the mean observed values

with females (Brawn 1961a, Hutchings et al. 1999, Bekkevold et al. 2002). In addition to mate competition, individuals of both sexes might be expected to prefer large individuals as mates (Rowe et al. 2007), given that fecundity and sperm volume increase with body size (Trippel \& Morgan 1994a, McIntyre \& Hutchings 2003). The choice of large males by females, for example, may increase the probability that sufficient sperm is available to fertilize a female's batch of eggs. Also, by choosing a behaviourally dominant male, a female may be able to reduce the probability of a disruption in courtship by other males. Consequently, one interpretation of the paternity patterns in our study is that the male siring the most offspring was the male that most often elicited egg release by the female, although this could not be verified by the video observations. Only 6 spawning events were recorded on video and although all clearly involved satellite males, it was often not possible to determine the identities of individuals involved and, thus, link male behaviour during spawning to parentage data. Unfertilized cod eggs and sperm remain viable for $>1 \mathrm{~h}$ in seawater (Kjørsvik \& Lønning 1983, Trippel \& Morgan 1994b), potentially enabling sperm to compete for fertilization during a long period following ejaculation. Ejaculating sperm, even when not engaged in a ventral mount with a spawning female, may enable some males to acquire some reproductive success. Therefore, it is possible that larger males may have sired more offspring simply by having larger ejaculates (Trippel \& Morgan 1994a), rather than because they acquired more matings.

Our behavioural and genetic data are consistent with the hypothesis that alternative mating tactics exist in male Atlantic cod (Hutchings et al. 1999). Multiple males appeared to release sperm in all spawning events, even though typically only 1 male engaged in a ventral mount with the spawning female. Accordingly, the number of ventral mounts initiated (i.e. mating success) was not a strong predictor of reproductive success and several males in our spawning groups sired substantial numbers of offspring seemingly without having initiated much agonistic activity (although we cannot exclude the possibility that these individuals also engaged in courtship and aggressive activity but outside our periods of daily observation; Fig. 3). Unlike some other fishes that exhibit 'bourgeois' and 'parasitic' male forms (Taborsky 1998), there do not appear to be morphological differences between male Atlantic cod employing alternative mating tactics. Interestingly, our estimates of reproductive success between 1 and $5 \%$ for individual satellite males are consistent with those in salmonids (Jones \& Hutchings 2001, 2002). The ability of some males to sire offspring without courting females or aggressively competing with other males may partially explain weak relationships apparent between reproductive success and some of the morphological traits examined.

Reproductive success was highly variable amongst males, with comparatively few individuals being responsible for most of the eggs spawned within a breeding group. Although previous work has suggested that paternity frequencies may be skewed (Brawn 1961a, Hutchings et al. 1999, Rakitin et al. 2001, Bekkevold et al. 2002), we examined male reproductive success in captive groups of 52 to 93 individuals, group sizes that, at a minimum, are more than 3 times larger than any examined in the past. Reproductive skew appeared particularly high in Group 4, in which 1 male sired approximately $68 \%$ of the offspring and $54 \%$ of males sired no offspring. Our data are consistent with a 
recent study which suggests that skew in reproductive success increases with variability in male body size (Bekkevold 2006). Our results also lend credence to analyses that have suggested that the ratio of effective to census population size in broadcast-spawning marine fishes is very small (ranging between $10^{-2}$ and $10^{-5}$; e.g. Hedgecock 1994, Hoarau et al. 2005).

We cannot exclude the possibility that our experimental facility may have influenced the observed patterns of spawning behaviour and reproductive success. Although little is known about cod spawning behaviour in the wild, one can assume that spawning groups under natural conditions are open systems comprising individuals free to move in response to social or environmental cues. Captivity may have altered female availability or male reproductive strategies relative to those found in nature, although we have no information regarding whether this is actually the case. Densi-

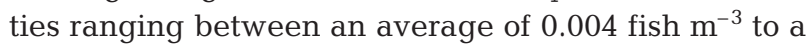
maximum of 0.488 fish $\mathrm{m}^{-3}$ have been reported for spawning aggregations in nature (Morgan et al. 1997), which does not preclude the possibility that males establish territories of a size similar to those that have been described in captivity (Brawn 1961a). The tank used to conduct our experiments has the largest volume of any ever used to study the spawning behaviour of a marine fish. In addition, because we used a closed system, we were able to collect all eggs produced by spawning females in our study groups and randomly sample offspring to determine parentage and estimate relative reproductive success of individuals.

High skew in male reproductive success with larger, more aggressive males siring a greater number of offspring than smaller, less aggressive males is consistent with the hypothesis that cod reproduce within the behavioural constructs of a lekking mating system (Hutchings et al. 1999, Nordeide \& Folstad 2000). In leks, males cannot monopolize resources to gain matings with females, and females typically discriminate among potential mates based on their dominance and sexually selected traits (Höglund \& Alatalo 1995). Lekking is often characterized by high variance in male reproductive success, with behaviourally dominant and more attractive individuals engaging in a disproportionate share of matings. With the exception of some cichlids, leks have rarely been described in fishes (Höglund \& Alatalo 1995).

The present study has revealed a consistently positive influence of body size and aggression on reproductive success in male Atlantic cod. Our work suggests that the size of the pelvic and median fins may also be of importance during the mating embrace (Skjæraasen et al. 2006) or courtship displays (Engen \& Folstad 1999), respectively. These observations imply that reproduction is not random with respect to male phenotype in this species and that the mating systems of broadcast-spawning marine fishes are considerably more complex than has been depicted (see references in Nordeide \& Folstad 2000). Modified to some extent by the contributions of sperm from satellite-spawning males, reproductive success is highly skewed. In concert with future studies that focus on how these correlates of reproductive success influence mate competition and mate choice, we suggest that there is merit in determining the influence of alternative mating tactics on individual variability in reproductive success and effective population size in Atlantic cod and other broadcast-spawning marine fishes.

Acknowledgements. Thanks to T. R. Birkhead, D. G. Kehler, R. A. Myers, P. D. Taylor, and 3 anonymous reviewers for their insightful comments on a previous version of this manuscript. We are grateful to P. Avendaño, J. D. Eddington, and S. Thompson for providing technical assistance in the lab. Parentage analysis would not have been possible without the help of R. M. Gillett, M. W. Jones, and C. Smith. Logistical support for fish collections was provided by Fisheries and Oceans Canada and Inshore Fisheries Limited. Financial support was provided by the Natural Sciences and Engineering Research Council of Canada and by the Norwegian Research Council.

\section{LITERATURE CITED}

Avise JC, Jones AG, Walker D, DeWoody JA and 7 others (2002) Genetic mating systems and reproductive natural histories of fishes: lessons for ecology and evolution. Annu Rev Genet 36:19-45

Bekkevold D (2006) Male size composition affects male reproductive variance in Atlantic cod Gadus morhua L. spawning aggregations. J Fish Biol 69:945-950

Bekkevold D, Hansen MM, Loeschcke V (2002) Male reproductive competition in spawning aggregations of cod (Gadus morhua, L.). Mol Ecol 11:91-102

Brander K (1994) Spawning and life history information for North Atlantic cod stocks. ICES Coop Res Rep 205

Brawn VM (1961a) Reproductive behaviour of the cod (Gadus callarias L.). Behaviour 18:177-198

Brawn VM (1961b) Sound production by the cod (Gadus callarias L.). Behaviour 18:239-255

Chambers RC, Waiwood KG (1996) Maternal and seasonal differences in egg sizes and spawning characteristics of captive Atlantic cod, Gadus morhua. Can J Fish Aquat Sci 53:1986-2003

COSEWIC (Committee on the Status of Endangered Wildlife in Canada) (2003) COSEWIC assessment and update status report on the Atlantic cod Gadus morhua, Newfoundland and Labrador population, Laurentian North population, Maritimes population, Arctic population, in Canada. COSEWIC, Ottawa

Crawley MJ (2002) Statistical computing: an introduction to data analysis using S-Plus. John Wiley \& Sons, Chichester

DeWoody JA, Fletcher DE, Mackiewicz M, Wilkins SD, Avise JC (2000) The genetic mating system of spotted sunfish (Lepomis punctatus): mate numbers and the influence of male reproductive parasites. Mol Ecol 9: 2119-2128

Duchesne P, Godbout MH, Bernatchez L (2002) PAPA (package for the analysis of parental allocation): a computer 
program for simulated and real parental allocation. Mol Ecol Notes 2:191-193

Engen F, Folstad I (1999) Cod courtship song: a song at the expense of dance? Can J Zool 77:542-550

Hedgecock D (1994) Does variance in reproductive success limit effective population sizes of marine organisms? In: Beaumont AR (ed) Genetics and evolution of aquatic organisms. Chapman \& Hall, London, p 122-134

Hoarau G, Boon E, Jongma DN, Ferber S and 5 others (2005) Low effective population size and evidence for inbreeding in an overexploited flatfish, plaice (Pleuronectes platessa L.). Proc R Soc B 272:497-503

Höglund J, Alatalo RV (1995) Leks. Princeton University Press, Princeton, NJ

Hutchings JA, Bishop TD, McGregor-Shaw CR (1999) Spawning behaviour of Atlantic cod, Gadus morhua: evidence of mate competition and mate choice in a broadcast spawner. Can J Fish Aquat Sci 56:97-104

Jones MW, Hutchings JA (2001) The influence of male parr body size and mate competition on fertilization success and effective population size in Atlantic salmon. Heredity 86:675-684

Jones MW, Hutchings JA (2002) Individual variation in Atlantic salmon fertilization success: implications for effective population size. Ecol Appl 12:184-193

Kjesbu OS, Solemdal P, Bratland P, Fonn M (1996) Variation in annual egg production in individual captive Atlantic cod (Gadus morhua). Can J Fish Aquat Sci 53:610-620

Kjørsvik E, Lønning S (1983) Effects of egg quality on normal fertilization and early development of the cod, Gadus morhua L. J Fish Biol 23:1-12

McIntyre TM, Hutchings JA (2003) Small-scale temporal and spatial variation in Atlantic cod (Gadus morhua) life history. Can J Fish Aquat Sci 60:1111-1121

Miller KM, Le KD, Beacham TD (2000) Development of triand tetranucleotide repeat microsatellite loci in Atlantic cod (Gadus morhua). Mol Ecol 9:238-239

Møller AP, Legendre S (2001) Allee effect, sexual selection and demographic stochasticity. Oikos 92:27-34

Morgan MJ, DeBlois EM, Rose GA (1997) An observation on the reaction of Atlantic cod (Gadus morhua) in a spawning shoal to bottom trawling. Can J Fish Aquat Sci 54 (Suppl 1):217-223

Editorial responsibility: Charles Birkeland,

Honolulu, Hawaii, USA
Myers RA, Mertz G, Bishop CA (1993) Cod spawning in relation to physical and biological cycles of the northern North-west Atlantic. Fish Oceanogr 2:154-165

Nordeide JT, Folstad I (2000) Is cod lekking or a promiscuous group spawner? Fish Fisheries 1:90-93

O'Reilly PT, Canino MF, Bailey KM, Bentzen P (2000) Isolation of twenty low stutter di- and tetranucleotide microsatellites for population analyses of walleye pollock and other gadoids. J Fish Biol 56:1074-1086

O'Reilly PT, McPherson AA, Kenchington E, Taggart C, Jones MW, Bentzen P (2002) Isolation and characterization of tetranucleotide microsatellites from Atlantic haddock (Melanogrammus aeglefinus). Mar Biotechnol $4: 418-422$

Quader S (2005) Mate choice and its implications for conservation and management. Curr Sci 89:1220-1229

Rakitin A, Ferguson MM, Trippel EA (2001) Male reproductive success and body size in Atlantic cod Gadus morhua L. Mar Biol 138:1077-1085

Rowe S, Hutchings JA (2003) Mating systems and the conservation of commercially exploited marine fish. Trends Ecol Evol 18:567-572

Rowe S, Hutchings JA (2004) The function of sound production by Atlantic cod as inferred from patterns of variation in drumming muscle mass. Can J Zool 82:1391-1398

Rowe S, Hutchings JA (2006) Sound production by Atlantic cod during spawning. Trans Am Fish Soc 135:529-538

Rowe S, Hutchings JA, Skjæraasen JE (2007) Nonrandom mating in a broadcast spawner: mate size influences reproductive success in Atlantic cod (Gadus morhua). Can J Fish Aquat Sci 64:219-226

Skjæraasen JE, Rowe S, Hutchings JA (2006) Sexual dimorphism in pelvic fin length of Atlantic cod. Can J Zool 84: 865-870

Taborsky M (1998) Sperm competition in fish: 'bourgeois' males and parasitic spawning. Trends Ecol Evol 13: 222-227

Trippel EA, Morgan MJ (1994a) Age-specific paternal influences on reproductive success of Atlantic cod (Gadus morhua L.) of the Grand Banks, Newfoundland. ICES Mar Sci Symp 198:414-422

Trippel EA, Morgan MJ (1994b) Sperm longevity in Atlantic cod (Gadus morhua). Copeia 1994:1025-1029

Submitted: February 1, 2007; Accepted: July 7, 2007

Proofs received from author(s): January 2, 2008 